\title{
CHANGES OF FUTURE EDUCATION MODEL
}

\author{
Ro'ifah \\ Universitas Muhammadiyah Surabaya \\ roifah@um-surabaya.ac.id
}

\begin{abstract}
ABSTRAK
Teknologi dengan cepat mengubah dunia di sekitar kita. Ini berkembang sangat cepat sehingga dapat menjawab hampir setiap orang secara instan. Banyak driver seperti konektivitas global, mesin pintar, dan media baru membentuk kembali bagaimana orang berpikir, bagaimana orang belajar serta mengembangkan keterampilan di masa depan. Banyak orang merasa terganggu bahwa teknologi akan menggantikan kecerdasan manusia. Bahkan, ada kekhawatiran bagi beberapa pendidik bahwa tidak akan ada siswa yang mengajar lagi di masa depan karena teknologi mungkin mengambil alih banyak tugas dan kemampuan yang telah diajarkan pendidik kepada siswa selama beberapa dekade. Tapi apa artinya ini bagi pendidikan di masa depan? Ketika kita mulai semakin bergantung pada komputer untuk menjawab pertanyaan kita, itu akan membuat kita kehilangan kemampuan untuk menjawab diri kita sendiri. Pendidikan tidak akan pernah hilang. Itu hanya akan mengambil model yang berbeda. Perlahan tapi pasti, semua tingkat pendidikan akan mengubah model pendidikan. Ada delapan hal yang akan membentuk masa depan pendidikan untuk dua puluh tahun ke depan; waktu dan tempat yang beragam, pembelajaran yang dipersonalisasi, pilihan bebas, berbasis proyek, pengalaman lapangan, perubahan dalam ujian yang diselesaikan, kepemilikan siswa, dan bimbingan yang lebih penting. Kajian ini diharapkan mampu menjawab pertanyaan dan mengurangi kecemasan yang beredar di masyarakat selama ini.
\end{abstract}

Katakunci: bimbingan, kepemilikan siswa, pembelajaran yang dipersonalisasi

\section{ABSTRACT}

Technology is rapidly changing the world around us. It develops so fast that it can answer almost every person question instantly. Many drivers such as global connectivity, smart machines, and new media are reshaping how people think, what shapes, and how people learn and develop skills in the future. Many people feel disturbed that technology will replace human intelligence. In fact, there are concerns for some teachers that there will be no students teaching again in the future because technology might take over many of the tasks and abilities teachers have taught students for decades. But what does this mean for future education? When we begin to rely more and more on computers to answer our questions, it will make us lose the ability to answer ourselves. Education will never disappear. It will only take a different model. Slowly but surely, all levels of education will change the educational model. There are eight things that will shape the future of education for the next twenty years; diverse times and places, personalized learning, free choice, project based, field experience, changes in completed exams, student ownership, and more important guidance.

Keywords: personalized learning, student ownership, mentoring

\section{INTRODUCTION}

The industrial age education model, the assembly line is based on a predetermined time, place, curriculum, and speed - not enough in today's society and knowledge-based economy. In some ways, education seems to be the same for years.

However, technology is advancing fast so that it can answer almost every person's question instantly. Technology has influenced almost every aspect of life today, 
including education. Education system must be fundamentally reengineered from mass production. The teaching model becomes a student-centered learning, addresses diversity in students' backgrounds and needs, and higher expectations for all students (Wolf, 2010, p. 2).

Many drivers such as global connectivity, smart machines, and new media are reshaping how people think, what shapes, and how people learn and develop skills in the future. Learning will become far more important, and different, for the next generation. Most people will have at least six different careers, requiring fundamental reeducation, while the speed of innovation will constantly require new skills and knowledge to keep pace.

\section{MODELS FOR FUTURE EDUCATION}

Due to technology is rapidly changing the world around us, many people worry that technology will replace human intelligence. Some educators are worried that no more students will be taught in the near future because technology will take over many of the tasks and abilities that we have taught our students for decades. But, what does this mean for the future of education? When we begin to rely more on computers to answer our questions, will we lose the ability to answer them ourselves? The problem: Education will never disappear. It will only take a different form. There are eight models that will color future education for the next twenty years.

\section{Diverse Times and Places}

Conventionally, our current education system is designed around sitting time. Students are required to progress only with the time spent physically in the school class for certain units or courses. The physical limitations of time and place can dramatically delay the flexibility needed to encourage and enable learning. In addition, the implementation of models offer such as flexible learning time and place for online or mixed learning and experience in the community are often limited by several policies.

On the other hand, in the next twenty years, flexible learning, anytime / anywhere including learning outside of traditional school days or building through online or mixed learning, direct opportunities in the community, and instruction offered by various teachers, experts, or technology (Wolf, 2010, p. 7). Adding virtual educators to digital content creates various models of online learning and is mixed to personalize education for each child.

By offering learning opportunities from anywhere, education can be variable and learning cannot be constant, and 
by providing access to courses and instructors are often not available in schools. Furthermore, students will have more opportunities to study at different times in different places. E-Learning tools make opportunities easy for distance learning and self-paced. Classes will be reversed, which means the theoretical part is studied outside the classroom, while the practical part must be taught directly, interactively.

\section{Personalized Learning}

Personalization is often confused with terms related to individualization and differentiation, which often occur in education. True personalization goes further and requires major changes in the focal point of the institutional / teacher approach that is centered on an authentic and student-centered approach. True personalization provides programs and learning approaches that are specifically tailored to the abilities, interests, preferences, and other needs of each student.

Personal learning is not about technology itself; Technology is an important driver and means of changing one size system for all of us today. Students will learn with all kinds of tools that adapt to students' abilities. This means that above average students will be challenged with more difficult tasks and questions when a certain level is reached. Students who have difficulty with subjects will get the opportunity to practice more until they reach the required level. Students will be positively strengthened throughout their individual learning process. This can result in a positive learning experience and will reduce the number of students losing confidence about their academic abilities.

Personalized learning is instruction that offers pedagogy, curriculum, and learning environments to meet the needs of individual students. This experience is tailored to the learning preferences and special interests of different students. In personalized learning environments, learning objectives and content, as well as methods and steps, can all vary. Personalization also includes different instructions that support student progress based on mastery of subject matter / Competency-Based Progression / Pac (Wolf, 2010, p. 9).

Furthermore, the teacher will be able to clearly see which students need help in what areas. Personalized learning allows teachers to determine what students don't understand so they can better target interventions to help students get back on track. 
Simultaneously, this also helps many students who may be at different levels of mastery so students can progress through content at their own pace without worrying about being too far behind (or in front) of their classmates. In addition, this allows students to take ownership of learning and understand how they learn, so they can be better prepared to take action, set goals, and determine what support they need.

\section{Free Choice}

Children in early care spend most of their day in educational programs. Although each subject taught aims for the same goal, the path to that goal can vary per student.

However, the free choice given to them also seems to make students more challenging themselves. In this case, future learning will use the Choices board (learning menu), activities or assignments that give students the choice to choose what they will do to meet the requirements. As a general rule, this board draws various teaching options targeted at specific academic goals. The choice board makes students more involved. They can be arranged in a variety of different ways: with abilities, intelligence, learning styles, student interests, readiness, learning preferences, or even questions. As a tip, it's best to focus only on one of these types when making boards.

Students will never work on the same task and if they make their learning look different. Students have their own private workspace; but they are also free to sit anywhere in the room and in learning. Sometimes students need a quiet space to record something, and sometimes they need a space where they can collaborate with their peers. The mentor or teacher will encourage spoken language in the classroom, and collaboration. The classroom is a place where mentors encourage inquiry, miracles and inquiry. Allows students to choose to make sure they meet the learning objectives, as well as to digest the material in the way that best suits their learning style. In addition, students will be able to modify their learning process with tools they feel are needed for them in the future. Students will learn with different devices, different programs and techniques based on their own preferences. Blended learning, reversing classrooms and $B Y O D$ (Bring Your Own Device) form an important terminology in this change.

\section{Project Based}

Project-based learning (PBL) is a student-centered pedagogy 
that involves a dynamic classroom approach in which it is believed that students gain deeper knowledge through active exploration of challenges and realworld problems. Subjects by working for a long time to investigate and respond to complex questions, challenges, or problems will be studied by students. This is an active learning style and inquiry-based learning. PBL contrasts with paper-based, memorizing, or teacher-led instructions that only present existing facts or describe a smooth path to knowledge by asking questions, problems or scenarios. PBL not only implements meaningful learning but students' learning processes and the depth of their cognitive involvement not the products produced - which distinguishes projects from busy work (Larmer and Mergendoller, 2010, p. 35).

Closely related to the concept of authentic learning, project-based learning experiences are often designed to address real-world problems and problems, which require students to investigate and analyze complexities, inter-connection, and their ambiguity (that is, there may not be "right" or "wrong" answers in project-based learning assignments). For this reason, project-based learning can be called inquiry-based learning or learning by doing, because the learning process is an integral part of the knowledge and skills acquired by students.

Project-based and authentic learning opportunities can help improve the relevance of learning and enhance students' ability to apply knowledge and use critical thinking skills (O'Brien, 2019). Educational leaders see this as an instructional shift to one that is better able to integrate meaningful content and $21^{\text {st }}$ century skills and to meet the interests and learning styles of many students. Students generally agree that project-based and authentic learning opportunities can therefore help increase student involvement and ongoing attention, which increases the likelihood of learning and achievement.

\section{Field Experience}

Student field experience is the opportunity for students to apply the knowledge gained in the classroom by way of supervised practice in the field. Field experience is often seen as one of the most critical elements for students. Future education will provide opportunities for students to integrate theory and practice. Students will be asked to participate in a variety of diverse field / clinical experience settings (rural, suburban, and urban with 
various

socioeconomic

demographics).

Due to technology can facilitate more efficiency in certain domains, the curriculum will provide space for skills that merely require human knowledge and face-to-face interaction. As such, experience in the 'field' will be emphasized in the course. Schools will provide more opportunities for students to acquire real-world skills that represent their work. This means the curriculum will create more space for students to fulfill internships, mentoring projects and collaborative projects.

Field-based experience in secondary schools makes it possible to participate in classroom activities and in one full day teach selected scientific concepts in outdoor settings (Haciomeroglu, 2013, p. 135). Field experience concentrates more on roles and experiences. That's why it's often done in early laboratories and clinical experience, internships, reading guidance, math guidance, clinical interviews, science days, etc.

\section{Completed Exam Change}

Exams are important and always will be. The main exams are a curse for many students. As a result, this raises this phenomenon: "Tomorrow is my test, but I don't care because a piece of paper cannot determine my future" or "The results of the exam do not determine success in life". Isn't that very easy to say? They represent a one-time opportunity to scribble months or years of study on paper, and can make or break a student's future career prospects. The problem is that taking the exam at the time specified by the academic calendar is never the ideal way to determine competence - they might come at the right time for some lucky students, but not for many others.

On the other hand, technology provides many opportunities as Wolf argues. Technology can expand valuations to include more dynamic options, including embedded or formative assessments, especially with online or portfolio options (Wolf, 2010, p. 7). It is also possible to personalize the type of assessment depending on standards, content, and children. This may include performancebased assessments, observations, or application of knowledge in a group and will likely involve flexibility in both the time and age of students. When teaching starts to move online, teachers do not need to wait any longer until the end of the course to do the assessment. Instead, computer software can assess understanding during the learning 
process itself by analyzing each mouse click and pressing student buttons. Students' abilities can now be accurately measured by software without a final exam.

\section{Student Ownership}

Student ownership is a feature that takes time to trust, but we can build it by focusing on three specific things: choice, voice, and leadership. Student ownership is often mistaken for student empowerment, student voice and student involvement. They are not synonyms. Instead, student ownership is the amount of investment students have in the topics and methods they learn, and the places where learning, teaching, and leadership occur anywhere in the entire education system.

In education, the actual trajectory of learning can be seen in the transition from teacher-led teaching to self-directed learning for life (Wiles, 2016). That line of ownership can be seen from doing on orders to do a lifetime. That is why so many people give up so much of their lives for the business we call education. The love of learning becomes so deep in themselves that it becomes the principle message they need to communicate with students under their guidance: live to learn and learn to live.

\section{More Mentoring}

In 20 years, students will fit in with so much independence in the learning process. Assistance will be the main for student success. Mentoring is redefined as the role of the teacher and expands the teacher. Many entrepreneurs believe that mentoring is not teaching. Mentoring is not always easy. Not every work can be done by other teachers. Well-intended criticism can easily seem like a negative criticism.

One of the most important and neglected aspects of education is having a mentor who is able to manage the difficulties of daily struggles and professional challenges. The ongoing combination of classroom guidance and professional development workshops at the same time seems to be the best strategy for improving classroom practice and student performance. Mentoring is motivated development. This is to develop individuals not only for the current work, but also for the future.

\section{Relationship-oriented} mentoring strives to provide a safe environment where the mentor shares any issues that affect his professional and personal success. Although specific learning goals or competencies can be used as a 
basis for creating relationships, it is more focused on these areas, such as work / life balance, selfconfidence, self-perception, and how personal influence professionals . e actual learning trajectory can be seen in the transition from teacher-led teaching to self-directed learning that is directed for life (Wiles, 2016). That line of ownership can be seen from doing on orders to do a lifetime. That is why so many people give up so much of their lives for the business we call education. The love of learning becomes so deep in them that it becomes the principle message they need to communicate with students under their guidance: live to learn and learn to live.

\section{CONCLUSIONS AND SUGGESTIONS}

These are exciting, provocative and potentially far-reaching challenges. For individuals and society, new educational tools and resources hold the promise of empowering individuals to develop a fuller array of competencies, skills and knowledge and of unleashing their creative potential. Indeed, many of the changes underway call to mind the evocative words of Irish poet William Butler Yeats that, "Education is not about filling a bucket but lighting a fire".

The time is right for a true paradigm shift: Education stakeholders understand the need for change to meet today's demands. The technologies now exist to bring personalized learning to scale. Further, students themselves want to learn in the way that helps them achieve their potential. The teachers have to prepare themselves to face dropout rate and other issues facing our education system. The challenge before us is to take the research on how students learn and to build upon the models that represent a true paradigm shift to provide all students with a new modern learning system.

\section{REFERENCES}

Haciomeroglu, G. 2013. The Field Experiences of Student Teachers and Effective Mathematics Teaching in Turkey. Australian Journal of Teacher Education. Vol. 38 No. 2, p. 132.

Lamer L. and Mergendoller J. R. 2010. Giving Students Meaningful Work. Educational Leadership. Vol. 68 No. 1, pp. 34-37.

O'brien, Maggie. 2019. What is Project Based Learning? Defined Stem. Retrieved from: https://www.definedstem.com /blog/what-is-project-basedlearning/ on October 28, 2018.

Wiles. 2016. Designing your Classroom to Prepare Students for 2020. Retrieved from: https://www.nureva.com/blog/ designing-your-classroom-toprepare-students-for-2020and-beyond [Online] on September 17, 2018. 
Wolf, Mary Ann. 2010. Innovate to Educate: System [Re] Design for Personalized Learning. Washington, DC: SIIA. 